\title{
STRATEGI KOMUNIKASI PEMASARAN JAM TANGAN MATOA DALAM MENINGKATKAN BRAND AWARENESS
}

\author{
Susanto', Afrina Sari ${ }^{2}$ \\ 1,2 Universitas Budi Luhur
}

\begin{abstract}
This research is about marketing communication strategies by Matoa Watches in increasing brand awareness. Marketing communication conducted by Matoa is more focused on marketing communication activities on social media and internet but also done through advertising, publications and sales promotion to rising a brand awarenes. In this research, researchers used a descriptive qualitative method using in-depth semi-structured interviewsas a data collection techniques to obtain complete information in accordance with what is needed by researchers. The conclusion from this study shows that every promotion mix undertaken by Matoa not only refers to increasing brand awareness to the community but there are several promotional mixes aimed at increasing sales such as sales promotion.
\end{abstract}

\author{
Keywords \\ Marketing Communication \\ Strategies, Intergrated \\ Marketing Communication \\ (IMC), Brand Awareness, \\ Promotion \\ Correspondence Contact \\ ssantolee@yahoo.com \\ afrina.sari@budiluhur.ac.id
}

\section{PENDAHULUAN}

Kemajuan pola pikir masyarakat dewasa ini mengalami perkembangan yang sangat cepat. Perubahan pada perilaku konsumen yang lebih mengedepankan kemudahan di segala aspek kehidupan menjadi hal yang tidak dapat dihindari lagi. Perkembangan informasi yang pesat, kecanggihan teknologi serta inovasi yang semakin meningkat baik dalam produk barang ataupun jasa menjadi satu kesatuan yang mendukung tuntutan konsumen di era globalisasi saat ini. Selain itu, tuntutan konsumen juga berpengaruh pada kondisi ekonomi saat ini, terlihat dengan munculnya pesaing-pesaing dan pasar-pasar baru yang secara tidak langsung menjadikan peluang terhadap perkembangan perusahan di masa depan namun juga akan menjadi boomerang atau ancaman bagi perusahaan untuk berkembang.

Pembentukan brand image atau citra perusahaan dapat dilakukan perusahaan atau individu sebagai langkah untuk bersaing dan unggul dari pesaing lainnya. Menjadi sangat krusial karena tanpa sebuah citra yang baik dan positif, perusahaan tidak akan bertahan lama, selain itu produk juga akan sulit dikenal ataupun diterima oleh konsumen, terutama konsumen baru.

Dalam hal ini sektor bisnis jam tangan juga tidak luput dari kecepatan perkembangan informasi dan teknologi, yang mengakibatkan persaingan dan tuntutan konsumen menjadi hal yang tidak bisa dihindari lagi. Salah satu contohnya adalah Matoa, sebagai sebuah perusahaan jam tangan kayu pertama di Indonesia yang berdiri sejak tanggal 23 Maret 2012. Jam tangan Matoa menunjukkan keunggulan produknya yang merupakan perpaduan dari seni, kreativitas dan teknologi. Akan tetapi keunggulan dari sebuah produk menjadi tidak lengkap apabila masyarakat tidak mengetahuinya. Sebuah permasalahan mengenai kurangnya kesadaran merek (brand awareness) akan keberadaan jam tangan Matoa. Matoa sendiri masih bisa dibilang kurang popular dan belum bisa dijadikan pilihan utama ketika memutuskan untuk membeli jam tangan kayu. 
Penelitian dari M. Nurreza, Mahasiswa Ilmu KomuniaksiUPI 2016 dengan judul penelitian "Strategi Komunikasi Pemasaran PT. Bank Mandiri Kantor Wilayah Jawa 1 dalam Menarik Nasabah Mandiri Tabungan".Penelitian yang menggunakan analisis data dari Miles dan Huberman tersebut menunjukkan bahwa dalam mempromosikan produk yang dihasilkan oleh PT Bank Mandiri Kanwil Jawa 1, perusahaan tersebut menggunakan beberapa strategi komunikasi pemasaran seperti periklanan, publisitas dan personal selling. Selain itu strategi tersebut didasari dengan perencanaan pesan, penentuan metode, pelaksanaan dan evaluasi agar tujuan perusahaan dapat tercapai dengan baik.

Penelitian mengenai komunikasi pemasaran juga dilakukan oleh Ela Hulasoh, Mahasiswa Magister Imu Komunikasi Universitas Muhammadiyah Jakarta 2015, yang diberi judul "Komunikasi Pemasaran Terpadu Umroh ESQ Tours Travel (Sebuah Studi di PT. Fajrul Ikhsan Wisata). Penelitian yang didasari dengan Teori George dan Michael Belch ini menunjukkan bahwa produk-produk yang dihasilkan oleh ESQ Tour Travel telah dipromosikan dengan cukup baik, yaitu dengan menggunakan strategi komunikasi pemasaran meskipun belum maksimal dalam penerapannya, seperti dalam bidang promosi dan $p r$ namun terus menerus dilakukan evaluasi dan inovasi oleh tim manajemen sehingga yang akan datang tetap dan mampu menghadapi kompetitor yang tidak sedikit di bidang ini.

Melihat fenomena diatas, menunjukkan bahwa sebuah strategi dalam komunikasi pemasaran diperlukan guna mencapai tujuan dari perusahaan tersebut. Hal ini juga tidak terlepas dari suatu inovasi kreatif yang harus dipublikasikan demi keberlangsungan usaha tersebut, maka dari itu bagaimana caraMatoadalam menerapkan strategi komunikasi pemasaran yang dapat meningkatkan kesadaran akan merek Jam Tangan Matoa itu sendiri agar bisa bersaing dengan kompetitor - kompetitor pendahulunya.

\section{KAJIAN TEORITIK}

\section{Strategi}

Strategi merupakan cara dan arah yang digunakan oleh sebuah perusahaan atau individu dalam mencapai tujuan perusahaan serta memberikan keuntungan bagi mereka melalui pemanfataan sumber daya guna memenuhi kebutuhan serta permintaan pasar dan kepentingan para elit perusahaan. Strategi yang dilakukan tersebut biasanya bersifat jangka panjang, sehingga perencanaan yang matang sangat penting agar tujuan yang ditentukan bisa dicapai dengan baik.

Dalam buku yang berjudul Manajemen Pemasaran, Kotler menjelaskan bahwa strategi merupakan sebuat perekat yang digunakan untuk membentuk sebuah merek yang berbeda di pangsa pasar sehingga bisa menjadi nilai lebih bagi merek tersebut. Dalam sebuah bisnis penjualan, sebuah brand harus mempunyai keunggulan yang berbeda dari pesaingpesaingnya, gunanya agar brand tersebut dapat dikenali dengan baik dan bisa menjadi alasan produk tersebut tetap bertahan di pangsa pasar.

Dengan kata lain, sebuah perusahaan yang sedang memulai untuk membentuk citra perusahaan yang baik di pangsa pasar tidak hanya menciptakan strategi bagaimana produk perusahaan tersebut dijual, namun juga harus membentuk strategi yang baik untuk memposisikan dirinya ditengah masyarakat agar mempunyai ciri khas dibandingan rivalrivalnya.

\section{Komunikasi Pemasaran}

Komunikasi pemasaran adalah salah satu unsur penting dalam keseluruhan strategi pemasaran yang dilakukan oleh sebuah perusahaan, selain itu komunikasi pemasaran juga 
menjadi penentu suksesnya pemasaran tersebut. Komunikasi pemasaran yang baik tidak hanya meningkatkan jumlah penjualan dari sebuah produk tetapi juga turut membangun citra dari perusahaan produk tersebut.

Dalam beberapa decade terakhir ini, unsur komunikasi pemasaran menjadi sangat penting, dan menjadi satu kesatuan antara komunikasi dan pemasaran yang tidak dapat dipisahkan. Dalam penyampaian pesan kepada khalayak terutama target pasar yang dituju oleh sebuah perusahaan, biasanya perencanaan dari komunikasi pemasaran sudah dilakukan dengan matang, tujuannya agar pesan yang ingin disampaikan oleh perusahaan melalui produk yang dijual bisa diterima baik oleh konsumen/khalayak luas. Dewasa ini juga, perusahaanperusahaan mulai menyadari betapa pentingnya perencanaan komunikasi pemasaran dan mengintegrasikan hal tersebut untuk dijadikan sebagai elemen penting dalam dunia pemasaran dalam mencapai kesuksesan dan tujuan perusahaan

Menurut Moriarty dalam bukunya Periklanan Edisi ke-8, ada 3 tahap yang harus dilakukan oleh sebuah perusahaan sebelum melakukan serangkaian promosi penjualan ke khalayak luas. Hal itu mencakup yaitu penentuan tujuan pemasaran, penentuan segmentasi dan targeting, serta menentukan diferensiasi dan positioningproduk perusahaan tersebut. 3 tahap startegi komunikasi pemasaran yang dikemukan oleh Moriarty bertujuan agar produk maupun pesan yang ingin disampaikan oleh perusahaan bisa tepat sasaran. Berikut penjelasan mengenai ketiga tahap tersebut:

1. Penentuan tujuan komunikasi pemasaran.

Hal pertama yang harus dilakukan oleh perusahaan adalah menentukan tujuan pemasaran, hal ini menjadi penting agar strategi komunikasi pemasaran yang akan dirancang bisa sejalan dengan tujuan komunikasi pemasaran tersebut. Misalnya, apakah tujuan strategi komunikasi pemasaran yang akan dilakukan berfungsi untuk menaikkan penjualan produk, atau memperluas segmentasi pasar atau bahkan tujuan dari strategi tersebut hanya sekedar mengetahui kesadaran mayarakat mengenai produk perusahaan.

2. Penentuan segmentasi pasar dan Targeting.

Segmentasi pasar adalah cara untuk mengkategorikan kelompok masyarakat secara lebih spesifik dalam kategori tertentu, apakah kelompok tersebut sesuai dengan produk perusahaan yang akan diluncurkan. Segmentasi pasar menjadi sangat krusial dalam perencanaan startegi komunikasi pemasaran. Karena pesan yang akan disampaikan dalam rancangan startegi komunikasi pemasaran diharapkan bisa diterima oleh pasar dengan baik dan tidak salah. Selain itu, segmentasi pasar atau pembagian kelompok bisa dilakukan berdasarkan aspesk psikografis, demografis, perilaku dan manfaat serta aspek geografis. Sedangkan targetingadalah memfokuskan kegiatan pemasaran ataupun promosi penjualan pada satu atau beberapa kelompok konsumen.

3. Diferensiasiproduk dan Positioning.

Perusahaan harus mampu menentukan dimana titik perbedaan antara produknya sendiri dengan produk pesaingnya, hal ini bertujuan untuk menentukan bagaimana startegi komunikasi pemasaran yang akan dirancang dalam memperkenalkan atau memposisikan produk tersebut ke tengah-tengah masyarakat yang kooperatif untuk memenuhi kebutuhan dan keinginan konsumen. Diferensiasi produk bisa dilakukan dengan berbagai cara, misalnya perbedaan pada fitur, desain, warna ataupun kelebihan manfaat yang tidak dimiliki produk serupa. Positioning adalah strategi komunikasi pemasaran yang berkaitan dengan bagaimanacara berfikir khalayak terhadapproduk, merk atau perusahaan, sehingga menimbulkan penilaian tertentu. 
Startegi ini berfungsi untuk menciptakan perbedaan yang unik dan unggul antara produk perusahaan dengan produk pesaing yang sejenis.

Dalam buku Prinsip-prinsip Pemasaran, Kotler dan Armstrong menjelaskan bahwa Bauran Komunikasi Pemasaran merupakan sebuah perpaduan strategi dan teknik yang baik dari seluruh elemen promosi yang biasa digunakan oleh sebuah perusahaan untuk mencapai tujuannya. Elemen-elemen tersebut meliputi advertising (periklanan), sales promotion (promosi penjualan), personal selling (penjualan personal), public relations (hubungan masyarakat), dandirect marketing (pemasaran langsung).

Periklanan adalah sebuah komunikasi berbayar yang digunakan untuk membentuk kesadaran dan perilaku konsumen serta untuk menyebarluaskan informasi yang bertujuan untuk mendapatakan tanggapan dari khalayak luas. Dewasa ini, iklan menjadi salah satu cara yang ampuh dalam mencapai tujuan perusahaan, namun sebuah iklan bisa dikatakan berhasil apabila mampun untuk membentuk brand awareness di benak masyarakat dan mampu untuk membujuk serta menyakinkan khalayak untuk menggunakan produk tersebut. Dalam tujuan yang lebih spesifik, iklan harus mampu untuk membangun reputasi perusahaan di tengah masyarakat.

Promosi penjualanbiasanya dilakukan sebagai bentuk tambahan jangka pendek, yang biasanya digunakan oleh perusaahan untuk mendorong pembelian dan/atau penjualan produknya. Promosi penjualan yang baik tidak hanya bertujuan untuk meningkatan penjualan sebuah perusahaan, namun juga harus mampu menimbulkan sebuah dampak yang besar terhadap reputasi suatu merek secara positif.

Penjualan personal meliputi representasi perusahaan yang diwakili oleh wiraniaga perusahaan yang bertujuan tidak hanya mendorong pembelian sebuah produk, namun juga membangun hubungan baik dengan pelanggan. Biasanya personal selling dilakukan dengan menggunakan konsep komunikasi face to face/person to person, hal ini dilakukan agar tujuan personal selling bisa secara langsung dicapai. Penjualan personal dikategorikan sebagai salah satu alat yang efektif dalam membangun kepercayaan pelanggan dan mendorong keinginan pelanggan untuk membeli produk.

Hubungan masyarakatsalah satu cara unsur dalam bauran komunikasi pemasaran yang menghubungkan perusahaan dengan pelanggan dalam jumlah yang banyak. Seorang humas harus mampu menciptakan reputasi baik guna mencapai tujuan perusahaan, dalam hal ini Humas harus mampu membangun serta mendapatkan kepercayaan dari masyarakat. Selain itu, humas juga harus bisa menjadi jembatan yang baik antara perusahaan dan masyarakat, sehinggga public opinion yang muncul ditengah masyarakat tidak merugikan perusahaan.

Pemasaran langsungbiasanya dilakukan untuk menjalin hubungan baik dengan konsumen yang dilakukan secara langsung, agar hubungan yang diciptakan tersebut bisa bertahan lama/langgeng. Pemasaran langsung lebih menargetkan konsumen individual dengan pemanfaatan e-mail, social media, internet dan platform media lainnya.

\section{Brand Awareness}

Brand awareness atau kesadaran merek didefinisikan sebagai sebuah kesanggupan konsumen / calon pembeli dalam recognize atau mengenali bahwa suatu merek merupakan suatu bagian dari kategori produk tertentu. Dengan kata lain, konsumen mampu untuk mengenali dan juga menyebutkan suatu dalam sebuah kategori dengan mudah tanpa harus pengkategorian secara detail produk yang dimaksud. 
Dalam kesadaran merek atau brand awareness terdapat beberapa tingkatan yang berbeda. Tingkatan tersebut mencakup mengenai perasaan konsumen akan sebuah produk apakah produk tersebut dikenal oleh konsumen, atau bahkan produk tersebut sudah menjadi pilihan utama konsumen dalam pembelian produk kategori tertentu. Dalam bukunya yang berjudul Manajemen Ekuitas Merek, Aaker mengkategorikan tingkatan brand awareness menjadi empat tingkatan berikut ini:

1. Unware of brand. Pada tingkatan ini, calon pembeli belum yakin apakah sudah pernah menggunakan atau mengenali brand tersebut. Ini merupakan tingkatan kesadaran merek terendah, sehingga merek yang masuk dalam tingkatan ini harus mengkaji ulang strategi komunikasi pemasaran yang mereka lakukan.

2. Brand recognition. Tingkatan ini menunjukkan bahwa merek dapat dikenali serta calon pembeli mampu untuk mengingat kembali merek tersebut, serta mereka mampu untuk mengkategorikan merek yang dimaksud dengan menggunakan sedikit penjelasan atau stimulus mengenai merek tersebut.

3. Brand recall. Ketika sebuah merek sudah berada di tingkatan ini, kesadaran akan merek produk sudah bisa dikatakan baik, karena calon pembeli mampu untuk mengingat dan mengkategorikan merek yang dimaksud tanpa penggunaan stimulus.

4. Top of mind. Merupakan tingkatan tertinnggi pada tingkatan kesadaran merek, butuh waktu dan pengalaman yang baik untuk sebuah merek berada pada tingkatan ini. Dengan kata lain, setiap merek yang berada pada tingkatan ini memiliki strategi komunikasi pemasaran yang telah matang sehingga calon pembeli akansecara langsung mengingat merek tersebut sebagai yang pertama kali muncul dipikiran mereka saat kategori produk tersebut disebutkan.

Seperti yang digambarkan oleh David A. Aaker yang dikutip oleh Shimp (2007:35) berikut ini:

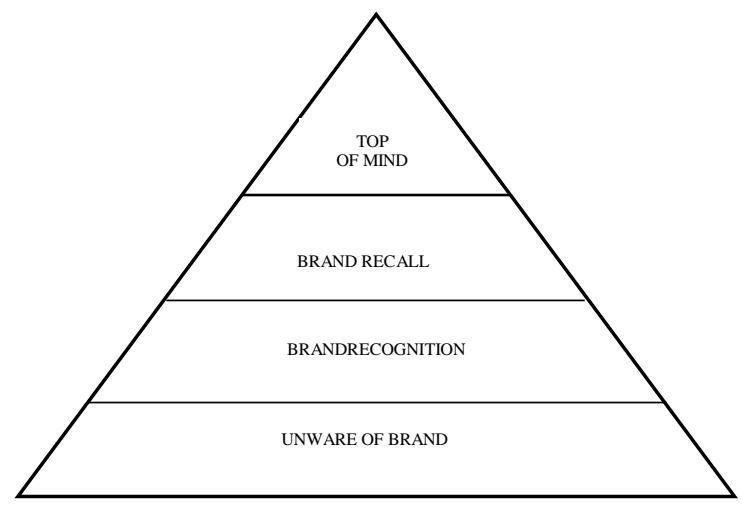

\section{METODOLOGI}

Menurut Bogdan dan Tailor, metodologi kualitatif merupakan sebuah prosedur penelitian yang bertujuan untuk menghasilkan data deskriptif berupa kata-kata tertulis atau lisan dari beberapa individu maupun perilaku dari individu tersebut. Agar penelitan mendapatkan sebuah data yang akurat peneliti menggunakanPendekatan kualitatif. Selain itu peneliti akan menggunakan teknik wawancara, dengan kata lain akan melibatkan pihak pertama dalam hal ini peneliti yang ingin mendapatkan informasi dari pihak lainya / informan dengan teknikpengajuanbeberapa pertanyaan tertentu yang bertujuan untuk melengkapi data penelitian peneliti. 
Selain itu, perolehan data juga dilakukan melalui dokumentasi, hal ini bertujuan untuk mencari data historis yang dimiliki suatu instansi atau perusahaan yang dituju. Penelitian ini menggunakan strategi pemasaran komunikasi yang dilakukan oleh Jam Tangan Matoa sebagai objek yang diteliti, dalam jangka waktu Oktober 2019-Desember 2019, dengan penentuanstaff Marketing Jam tangan Matoa dan Konsumen Jam tangan Matoa sebagai informan yang menjadi subjek penelitian,

\section{HASIL DAN PEMBAHASAN}

Hasil dalam penelitian ini bertujuan untuk mengetahui pengaruh dari strategi komunikasi pemasaran dalam membangun brand awareness Jam Tangan Matoa dengan tujuan untuk memperkenalkan dan mempromosikan Jam Tangan Matoa agar bisa diterima oleh konsumen, terutama konsumen baru.

Peneliti melakukan analisa melalui strategi komunikasi pemasaran yang dilakukan oleh Jam Tangan Matoa dengan menggunakan teori Brand Awareness dan Bauran Komunikasi dimana teori tersebut mencangkup strategi dan taktik pemasaran baru yang dilakukan oleh sebuah perusahaan dengan mengedepankan sebuah pendekatan pemasaran yang terintergrasi serta startegi tersebut lebihmengutamakan peran serta konsumen melalui keterlibatan mereka secara lebih mendalam dan dalam cakupan yang lebih luas yang secara tidak langsung mengantarkan nilai optimal dan mempromosikan produk kepada konsumen lainnya.

\section{Strategi Komunikasi Pemasaran Jam Tangan Matoa}

Dalam hal ini, baik itu perusahaan yang baru memulai ataupun yang sudah stabildan perusahaan yang bergerak dalam bidang apapun, mereka harus menyadari betapapentingnya komunikasi pemasaran, karena kegiatan komunikasi pemasaran tidak hanya mengenaicara untuk menumbuhkan dan memaksimalkanbrand awarenesssebuah produk dimasyarakat, namun juga akan berdampak pada peningkatan penjualan perusahaan tersebut. Dalam membentuk sebuah strategi komunikasi pemasaran yang baik tentunya diperlukan adanya pertimbangan dan pengenalan dari setiap lini yang bertujuan untuk memilih strategi apa yang tepat dan yang akan digunakan. Menyadari betapa pentingnya peran kegiatan dan strategi dalam sebuah komunnikasi pemasaran dalam meningkatkan image, berikut beberapa bentuk kegiatan komunikasi pemasaran yang telah dilakukan oleh Jam Tangan Matoa sampai saat ini.

Advertising. Hal yang paling utama dilakukan saat ini oleh Jam tangan Matoa adalah melakukan beriklan melalui media sosial instagram/twitter dan youtube. Internet (Media sosial)dirasa paling efektif karena jangkauan kepada konsumen sangat besar dan diharapkan dapat merambah keseluruh wilayah Indonesia. Iklan content creative yang disampaikan oleh Matoa memiliki keutungan tidak hanya secara emosional, tetapi juga mampumenumbuhkan serta meningkatkanawareness pada Jam Tangan Matoa dan secara tidak langsung meningkatkan image posited pada perusahaan tersebut. Intensitas beriklan menjadi strategi tersendiri yang lakukan oleh pihak Matoa dimana kegiatan komunikasi pemasaran yang mereka lakukan saat ini cukup agresif dengan pemanfataan seluruh platform media yang mereka gunakan untuk beriklan serta menampilkan brand mereka kepada dunia luar, dengan harapan bisa membangun awareness di tengah masyarakat. 

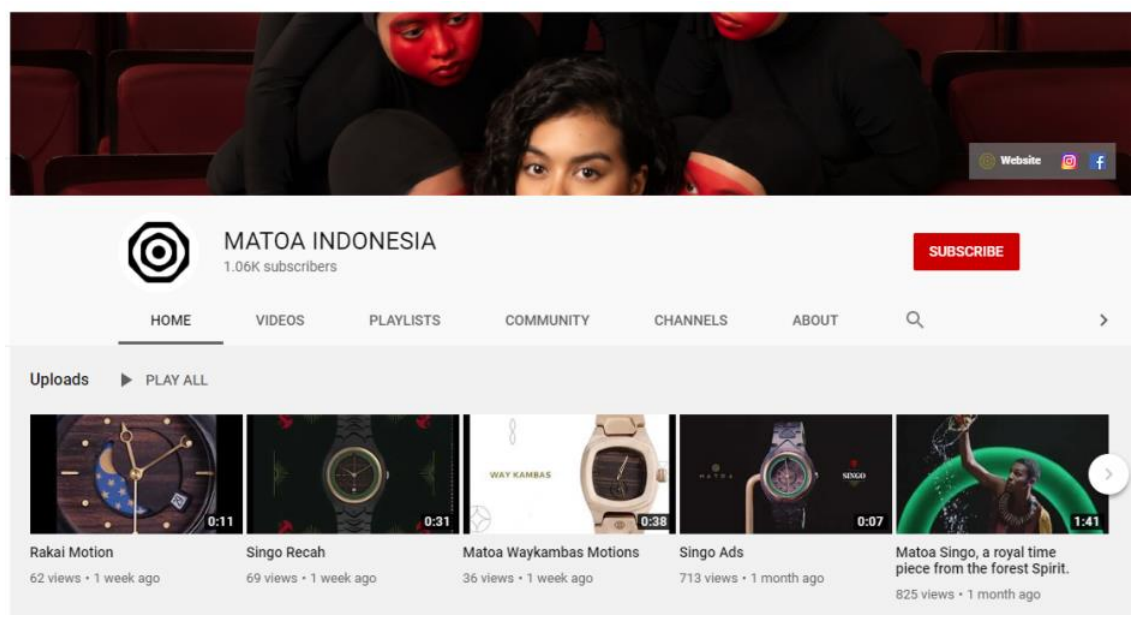

Gambar 1. Youtube Matoa Indonesia

Pada channel youtube Matoa Indonesia, dengan total lebih dari 1000 subscribers, Matoa Indonesia berusaha untuk membangun awareness dimasyarakat mengenai konsep Jam Tangan Matoa elegan dan eksklusif, karena diproduksi secara handmade. Terlihat dari beberapa video yang ditampilkan di channel youtube tersebut yang memperlihatkan produksi dari Jam Tangan Matoa.

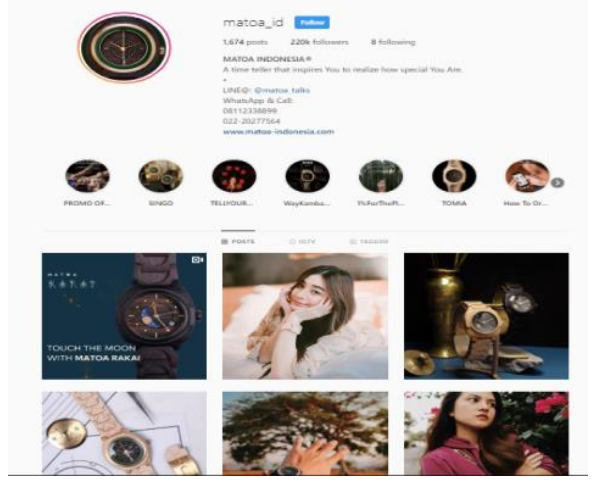

Gambar 2.

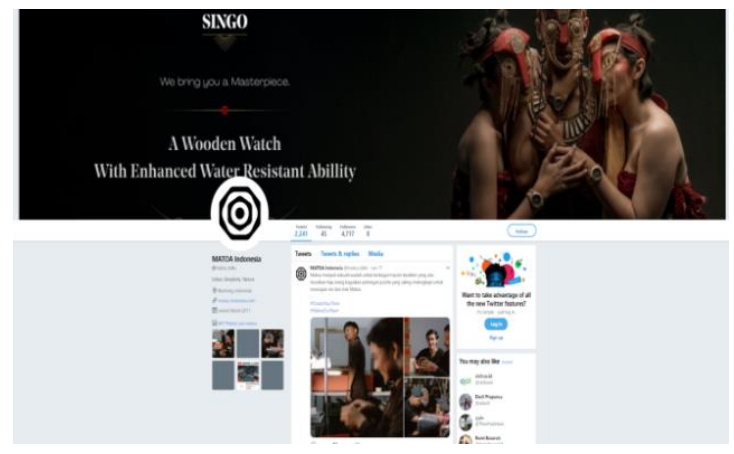

Gambar 3.

Instagram Matoa Indonesia

Twitter Matoa Indonesia

Tidak berhenti hanya pada promosi mengenai konsep produksi dari Jam Tangan Matoa Indonesia di channel youtubenya. Matoa Indonesia juga melakukan promosi melalui platform digitalInstagram dan Twitter, karena Matoa menyadari bahwa, segmentasi mereka adalah anak Milineal yang juga aktif di media sosial seperti Instagram maupun Twitter.

Promotion.Promosi yang dilakukan Matoa dalam meningkatkan ekuitas merek dirasa sudah cukup baik. Dengan adanya pemberian diskon, promo produk serta melibatkan artis Eva Cecilia, dengan tujuan konsumen mengetahui kegiatan promo yang dilakukan Matoa di media sosial. Selain itu Matoa juga melakukan beberapa pendekatan promosi, dengan mengikutsertakan konsumen dalam mempromosikan produknya, dengan memberikan testimoni dan rekomendasi kepada kerabatnya(refferal) sehingga bisa memdapatkan harga promo. Pemberian insentif seperti voucher, diskon harga dan sebagainya adalah sedikit 
contoh mengenai cara promosi penjualan untuk menarik konsumen dan masuk kedalam pangsa pasar.

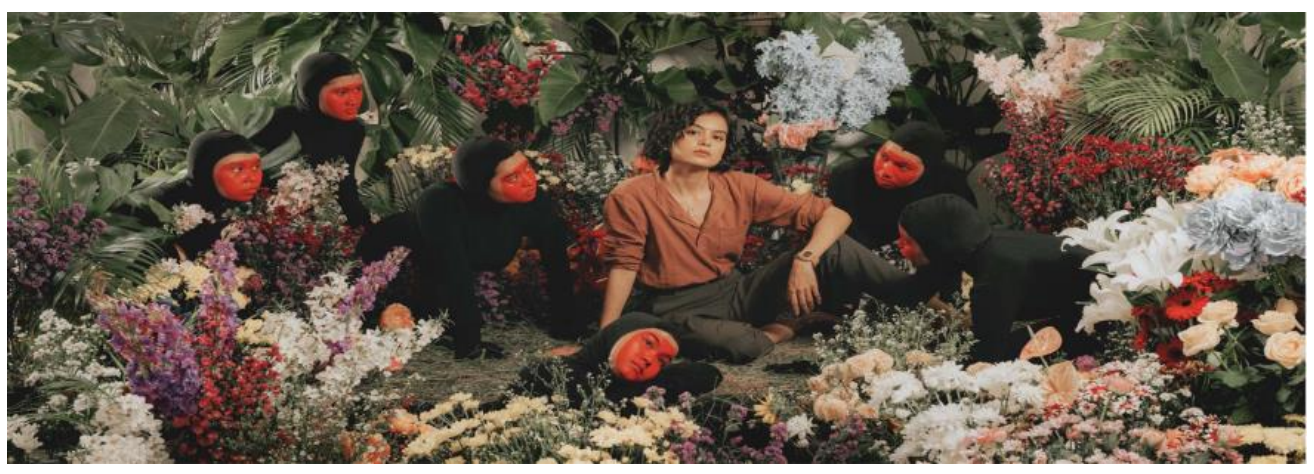

Gambar 4

Eva Cecilia sebagai Brand Ambassador Matoa Indonesia

Dalam campaign terbaru \#TellYourDifference, MATOA menggaet Eva Celia sebagai talent, MATOA berharap pesan dari campaign ini dapat terimplementasikan dengan maksimal. Eva Celia dipilih karena persona-nya yang kuat dan juga memiliki opini yang kuat mengenai "perbedaan", self-love, dan confidence.
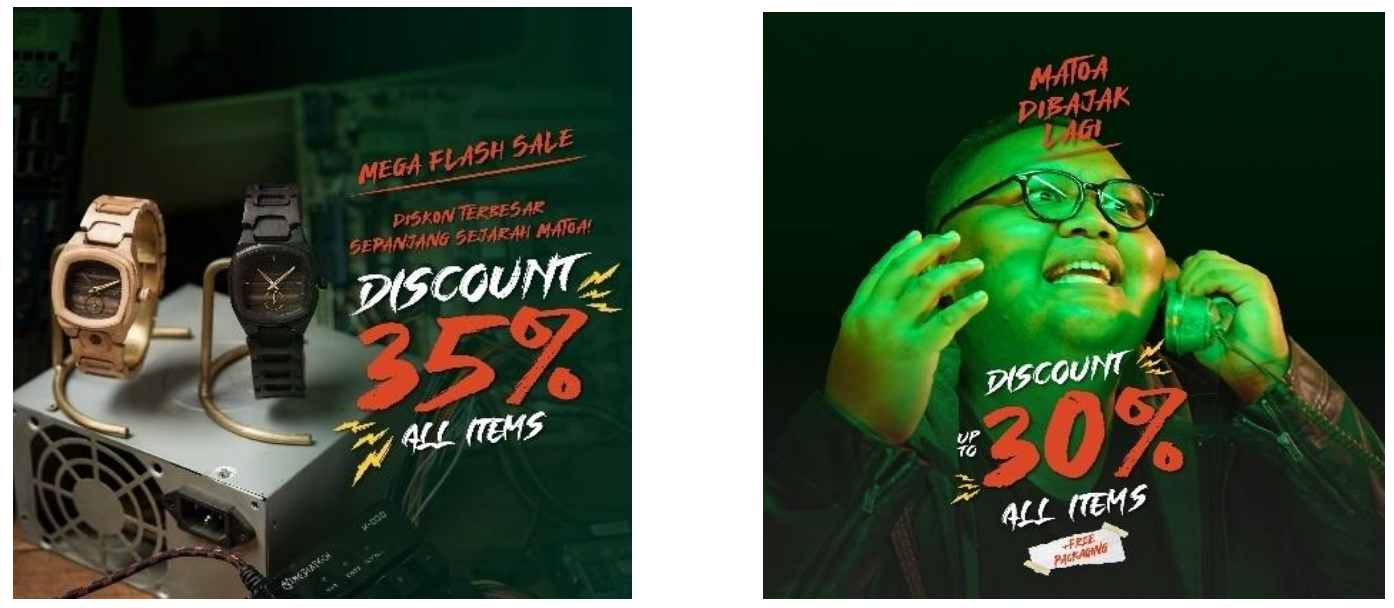

Gambar 5

\section{Discount Matoa Indonesia}

Matoa Indonesia juga sering melalui promosi melalui pemberian potongan harga untuk produk-produk yang dijual di website mereka. Potongan harga biasanya diberikan kepada konsumen existing melalui email, atau konsumen baru melalui iklan di website mereka.

Publicity. Kegiatan publisitas yang dilakukan oleh Matoa melalui internet sebagian besar adalah kegiatan marketing communication yaitu publikasi seperti menjadi sponsor dalam beberapa kegiatan sosial, ataupun terlibat dalam pameran yang bertemakan produk lokal. Selain itu, pembuatan berita mengenai kegiatan-kegiatan yang dilakukan oleh Matoa tidak bisa dipandang sebelah mata. Hal ini bertujuan untuk meminimalisircomplain negatif dari konsumen dan juga untuk menciptakan serta mempertahankan hubungan baik yang telah 
dijalankan oleh Matoa. Peningkatan product knowledge pada bagian internal perusahaan juga menjadi tidak kalah penting, sebagai cara perusahaan untuk menjaga service quality dari perusahaan kepada konsumen, agar informasi yang disampaikan jelas, maksimal serta baik dan benar.

Peran komunikasi pemasaran menjadi sangat penting dalam membangun brand awareness, karena berangkat dari hal itu, masyarakat dapat mengetahui lebih mengenai Jam Tangan Matoa. Kegiatan komunikasi pemasaran bertujuan untuk menciptkan brand loyalty dibenak masyarakat mengenai Matoa sebagai merek yang eksklusif dan dapat dinikmati oleh semua kalangan masyakarat.Pemanfaatan dan penggunaan digital/online yang digunakan oleh Jam Tangan Matoa juga turut medukung tujuan perusahaan itu sendiri,dan dalam hal ini pencapaian komunikasi yang baik terhadap produklah yang kemudian menjadi landasan bagi Jam Tangan Matoa untuk mempromosikan produknya kepada konsumen.

Apabila dikaitkan dengan tingkatan Brand Awareness Matoa dikalangan masyarakat, berdasarkan hasil wawancara produk Matoa bisa dikategorikan pada level Brand Recall, karena sebenarnya ada beberapa produk sejenis yang mungkin menjadi pilihan untuk beberapa konsumen dalam pemilihan jam tangan. Hal ini mungkin dikarenakan dari harga yang ditawarkan cukup tinggi dibandingkan produk sejenis lainnya, namun apabila dilihat dari Jenis bahan yang digunakan dalam proses produksi, harga tersebut menjadi setimpal. Maka dari itu,strategi komunikasi pemasaran yang dilakukan oleh Matoa harus lebih diperdalam, misalnya dengan menampilkan sebuah proses produksi, dari tahap perakitan yang bersifat handmade sampai siap untuk dijual. Selain iklan yang harus lebih menyentuh perasaan dan pikiran masyarakat, pengadaan promosi diskon dan voucher menjadi satu alat yang cukup ampuh untuk menaikkan level brand awareness Matoa dikalangan masyarakat.

\section{KESIMPULAN}

Fokus pemasaran yang Matoa gunakan adalah untuk meningkatkan brand awareness kepada konsumen bahwa Matoa adalah jam tangan kayu handmade yang prosesnya dibuat secara manual. Melihat gencarnya promosi yang dilakukan oleh Matoaterutama di media sosial ataupun internet. Secara umum setiap bauran promosi yang dilakukan oleh Matoa tidak hanya menunjuk kepada peningkatan brand awareness kepada masyarakan akan tetapi ada beberapa bauran promosi yang di tujukan untuk meningkatkan penjualan seperti sales promotion. Adapun bauran promosi yang dilakukan untuk meningkatkan brand awareness diantaranya adalah periklanan, promosi dan publisitas. Untuk saat ini sendiri bagi Matoa yang memang dirasa paling besar dalam meningkatkan kesadaran akan merek adalah melalui periklanan atau promosi dimedia sosial karena memiliki cakupan dan dampak yang lebih luas ke masyarakat.

\section{DAFTAR PUSTAKA}

Ardianto, Elvinaro. 2014. Metodologi Penelitian untuk Public Relations Kuantitatif dan Kualitatif. Bandung: Simbiosa Rekatama Media

A. Shimp, Terence. 2007. Periklanan Promosi (Aspek Tambahan Komunikasi Pemasaran Terpadu). Jilid 1, Edisi Terjemahan. Jakarta: Erlangga

Durianto, D., Sugiarto \& Sitinjak, T. 2004. Strategi Menaklukan Pasar Melalui Riset Ekuitas dan Perilaku Merek. Jakarta: PT Gramedia Pustaka Utama 
Effendy, Onong Uchjana. 2015. Ilmu, Komunikasi Teori dan Praktek Komunikasi. Bandung: PT. Citra Aditia Bakti

Fandy, Tjiptono, Ph.D. 2015. Strategi Pemasaran. Edisi 4. Yogyakarta: Andi

Hulasoh, Ela. 2015.Komunikasi Pemasaran Terpadu Umroh ESQ Tours Travel (Sebuah Studi di PT. Fajrul Ikhsan Wisata). Universitas Muhammadiyah Jakarta. Jakarta

Kennedy, Jhon E \& R. Dermawan Soemanagara. 2006. Marketing Communication. Jakarta: PT. Bhuana Ilmu Populer

Kotler, Philip \& Kevin Lane Keller. 2014. Manejemen Pemasaran Edisi 15. Jakarta: Erlangga

Kriyantono, Rachmat. 2014. Teknik Praktis Riset Komunikasi. Jakarta: Prenadamedia Group

Moriarty, Sandra \& Nancy Mitchells, William Wells. 2011. Advertising: 8th Edition. Jakarta: Kencana

Nurreza, Mohammad. 2016. Strategi Komunikasi Pemasasran PT. Bank Mandiri Kantor Wilayah Jawa 1 dalam Menarik Nasabah Mandiri Tabungan. Univeristas Padjajaran. Bandung

Patton, M. Q. 1990. Qualitative Evaluation and Research Methods. 2nd Ed. London: Sage Publication Lid.

Sugiyono. 2014. Metode Penelitian Pendidikan Pendekatan Kuantitatif, Kualitatif dan R\&D. Bandung: Alfabeta

Suyoto, Danang. 2013. Teori, Kuesioner dan Analisis Data: Untuk Pemasaran dan Perilaku Konsumen. Yogyakarta: Graha Ilmu

Uyung, Sulaksana. 2007. Integrated Marketing Communication. Jakarta: Pustaka Pelajar 